\title{
THE CORRELATION BETWEEN TRAINING, CAREER DEVELOPMENT AND EMPLOYEE PERFORMANCE WITH MODERATING VARIABLE OF JOB SATISFACTION : A CASE STUDY IN CAMBODIA
}

\section{Keomorakath PICH ${ }^{*}$, Fendy Suhariadi}

'Finance and Banking, PPIU Graduate Program, Master of Management, Filed in Human Resource Management, Faculty Economic and Business, University Airlangga.

Address: ' Jl. Airlangga No. 4 - 6, Airlangga, Gubeng, Surabaya, Jawa Timur, Indonesia 60115.

*Email: pich.keomorakath-2019@feb.unair.ac.id.

\begin{abstract}
This study aims to determine employee training and career development and whether the employee is satisfied. The next objective is that the result of this study is to find out the positive relationship impact of training and career development on employee performance with job satisfaction as a moderating variable. This study aims to analyze the data collected from hundreds of respondents working in a company located in Phnom Penh City, Cambodia. The data have been analyzed, applying the statistical techniques SPSS program with correlation, simple regression, and multiple regressions. The research was conducted by a survey sample of the questionnaires according to the theory related to training, career development, employee performance, and job satisfaction online. This paper uses a Quantitative Method to analyze the phenomenon through all level staff working in the company. The research result includes suggestions and recommendations to the phenomenon, which will help management improve employee ability and capacity to work quality and achieve the company goal.
\end{abstract}

Keywords: Training, career development, employee performance, job satisfaction.

JEL Classification: 015

Article History:

Received: June 2, 2021; Revised: August 6, 2021; Accepted: August 9, 2021; Available Online : August 28, 2021 DOI: $10.20473 / \mathrm{imtt.v14i2.27229}$

\section{INTRODUCTION}

The company's operation, human resources, or employees are the most valuable assets of a company, and the company needs to invest in that asset to achieve a company's goal. Employees have soft and hard skills because the training and development of an employee will help an employee perform better. Performance of individual to divided into three criteria as (1) individual task, (2) individual behavior, (3) individual characteristic (Suhariadi, 2013). Employee performance results from an employee's input and output behavior at work performing their duties with company goals. The phenomenon of employee performance experiencing increased productivity after attending training, and employees feel good with the company to develop their careers. They are satisfied working with the company according to other benefits, working conditions, and management-level support. They can make companies complete projects for customers and accept large projects from the 
government and the private sector. A few researchers focused on employees who work on skilled development for developing skills for their career advancement. Their willingness to do a job for a body always gives them knowledge by acting through training and development practice (Ahmad, 2013). Employee's regard as the main element of the company, both their success and failure, based on their abilities and to do Enable successful organizations to do training and training that can help staff get enough information about their work (Hafeez and Akbar, 2015). There have been limited studies concerned on research was showed a positive relationship between training and employees' retention and employee decision to stay for an extended period through training practice and training is more efficient the level of employee performance. Therefore, this study aims to examine the company's training, career development, job satisfaction, and employee performance. This study aims to analyze the effect of training, career development, and employee performance on job satisfaction. The gap of this study from previous research is that this research has a training and career development variable that positively impacts employee performance with job satisfaction as a moderating variable in various types of companies to do business.

\section{LITERATURE REVIEW AND HYPOTHESES}

The company needs to train and develop its employees because an employee is an important function to achieve the company goal and reach its plan.

\section{The Relationship between Training, Employee Performance, and Job Satisfaction}

Training is usually used to conduct any efforts initiated by an entity to encourage their staff to learn (Bohlander and Snell, 2010). Therefore, organizations need to train their human resources to acquire more skills and knowledge to win the competition (Krietner, 1995). That means that training will help employees master knowledge, skills, behaviors, sense of selfworth, and confidence upon which they can perform efficiently to improve on the performance of the organization. Performance management requires managers to ensure that employee's activities and outputs are congruent with the organization's goals and, consequently, help the organization gain a competitive advantage (Herman, 2009). A combination of three factors allows some people to perform at higher levels than others: (1) declarative knowledge, (2) procedural knowledge, and (3) motivation. Thus, three individual characteristics determine performance: procedural knowledge, declarative knowledge, and motivation. According to Ivancevich (1976) and Winda, Nayati, and Arik (2017), job satisfaction refers to an individual's general attitude towards his job. If the employees are satisfied with their jobs, they will bring a positive attitude to their jobs. A person with high job satisfaction holds a positive attitude towards the job, and one who is dissatisfied with it will have a negative attitude towards it. Measuring satisfaction from five aspects of an 
employee's job: work itself, pay, promotion opportunities, co-workers, and supervision. Moderating impact on job satisfaction, multiple correlation coefficients indicate that in some cases job satisfaction moderates the relationship between predicted and actual performance.

Based on the theoretical and empirical findings above, the hypothesis is derived. Training has a distinct role in achieving an organizational goal by incorporating the organization's interests and the workforce (Afroz, 2018). The researcher found that a strong relationship exists between employee training and employees' performance. Ivancevich (1976) argues that job satisfaction is defined as feelings or affective responses to facets of the work situation. The research was used job satisfaction as a moderator variable. The result that in the case of job satisfaction moderated the relationship between predicted and actual performance. High work satisfaction appears to be a moderator when examining unexcused absences, proficiency, quality, technical competence, and task orientation.

\section{$H_{1}$ : The impact of training on employee performance is positive.}

$\mathrm{H}_{2}$ : The impact of training on employee performance with job satisfaction as a moderating variable is positive and greater.

\section{The Relationship between Career Development, Employee Performance and Job Satisfaction} According to Winda et al. (2017) and Arifin, Raza, Saputra, and Puteh (2020), career development increases individual work abilities to achieve the desired career. Several indicators that need to be considered in career development are as follows: job performance, exposure, organizational loyalty, supervisor and sponsors, opportunities to grow. Meanwhile, several indicators that have a crucial role in career development supported by the human resources department are the role of leaders in career development and the role of feedback on career development. Performance management requires that managers ensure that employee's activities and outputs are congruent with the organization's goals and, consequently, help the organization gain a competitive advantage(Herman, 2009). A combination of three factors allows some people to perform at higher levels than others: (1) declarative knowledge, (2) procedural knowledge, and (3) motivation. Thus, three individual characteristics determine performance: procedural knowledge, declarative knowledge, and motivation. According to Ivancevich (1976) and Winda et al. (2017), job satisfaction refers to an individual's general attitude towards his job. If the employees are satisfied with their jobs, they will bring a positive attitude to their jobs. A person with high job satisfaction holds a positive attitude towards the job, and one who is dissatisfied with it will have a negative attitude towards it. Measuring satisfaction from five aspects of an employee's job: work itself, pay, promotion opportunities, co-workers, and supervision. Moderating impact on job satisfaction, multiple correlation coefficients indicate 
that in some cases job satisfaction moderates the relationship between predicted and actual performance.

Based on the theoretical and empirical findings above, the hypothesis is derived. Career development is vital for employees, as the activities are performed and indicated to the organization cares about their employees and them to develop (Hameed and Waheed, 2011). The researcher found that career development indirectly affected performance through motivation and organizational support as a moderator of the relationship between career development and performance. Paramita, Lumbanraja, and Absah (2020) argue that job satisfaction is the individual's general attitude to the job. The individual has to interact with co-workers and superiors, follow organizational rules and policies, and meet performance standards on the job. The researcher found that job satisfaction has a significant positive impact on employee performance.

$H_{3}$ : The impact of career development on employee performance is positive.

$\mathrm{H}_{4}$ : The impact of career development on employee performance with job satisfaction as a moderating variable is positive and greater.

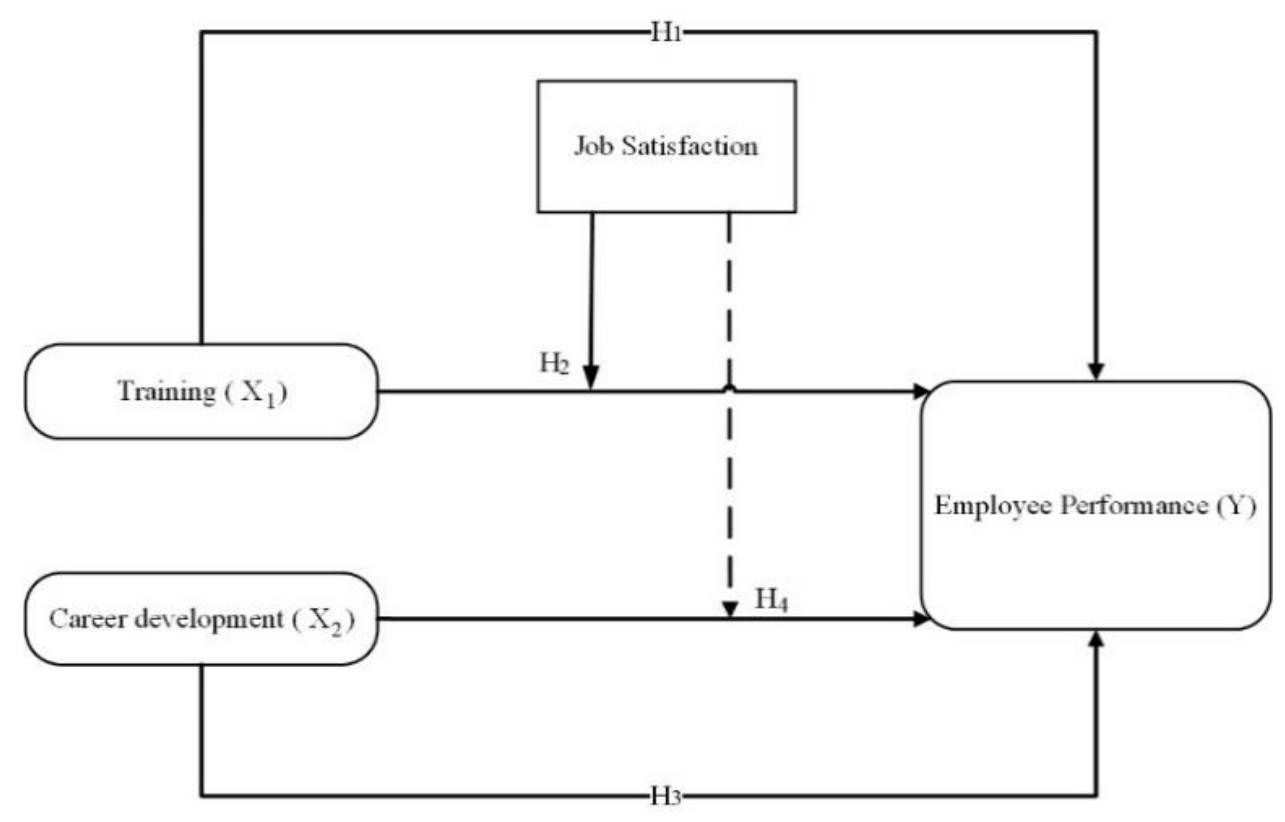

Figure 01. Conceptual Model 
Keomorakath PICH

Fendy Suhariadi

RESEARCH METHODS

Overview of Respondents

Table 1.

Demographic Overview of Respondents

\begin{tabular}{|c|c|c|c|}
\hline \multicolumn{2}{|c|}{ Characteristics } & $\mathbf{N}$ & $\%$ \\
\hline \multirow[b]{2}{*}{ Gender } & Male & 93 & 93.00 \\
\hline & Female & 07 & 7.00 \\
\hline \multirow[b]{2}{*}{ Age (years) } & Below 24 & 01 & 1.00 \\
\hline & $25-34$ & 99 & 99.00 \\
\hline \multirow{3}{*}{ Management Position } & Top Level Management & 03 & 3.00 \\
\hline & Middle-Level Management & 09 & 9.00 \\
\hline & Non-management staff & 88 & 88.00 \\
\hline \multirow{3}{*}{ Operational Area } & Site Department & 88 & 88.00 \\
\hline & Stock department & 05 & 5.00 \\
\hline & Operation Department & 07 & 7.00 \\
\hline \multirow{3}{*}{ Level of Educational } & Diploma Level & 85 & 85.00 \\
\hline & Bachelor's Degree & 14 & 14.00 \\
\hline & Master's Degree & 01 & 1.00 \\
\hline \multicolumn{4}{|c|}{$(N=100)$} \\
\hline
\end{tabular}

For this study, one hundred individuals were selected from the employee currently working at a company located in Phnom Penh City, Cambodia. In the demographic overview of respondents, we were selected respondents according to the general information of respondents. There is a division into five criteria, as shown in Table 1. All participants have used a Census survey from all the population. The total population is 100 respondents were selected for 31 questionnaires in this study and returned to provide useable data for further analysis. We collect the data online using Google Form for all respondents to fill the questionnaire by themselves.

\section{Variable Scales and Measurement}

This study has determined four variables are Training (T), Career development (CD), Employee Performance (EP), Job Satisfaction (JS). The measurement of the impact of training on employee performance from Bohlander and Snell (2010) and Krietner (1995), the impact 
of career development on employee performance from Winda et al. (2017) and Arifin et al. (2020), the impact of job satisfaction on employee performance as a moderating variable fromlvancevich (1976) and Winda et al. (2017), and employee performance that impact from T, CD, JS, scale from Herman (2009). We used points of the Likert scale, for each variable started from one (01) is strongly disagree until five (5) is strongly agree. The list of questionnaires to measure from each variable is shown in Table 2.

\section{Table 2.}

Questionnaire Items Conducted in the Main Survey

\begin{tabular}{|c|c|c|c|c|}
\hline Variables & Definition & Items & Descriptions & \\
\hline \multirow{4}{*}{$\mathrm{T}$} & \multirow{4}{*}{$\begin{array}{l}\text { An organization } \\
\text { initiates training to } \\
\text { learn their } \\
\text { employee's skills } \\
\text { and knowledge. }\end{array}$} & $\mathrm{T} 1$ & $\begin{array}{l}\text { (Skill) I have joint technical training at MA } \\
\text { HOUR Engineering, I develop my } \\
\text { technique skill. }\end{array}$ & \multirow{4}{*}{$\begin{array}{l}\text { (Bohlander } \\
\text { and Snell, } \\
\text { 2010) and } \\
\text { (Krietner, } \\
\text { 1995). }\end{array}$} \\
\hline & & $\mathrm{T} 2$ & $\begin{array}{l}\text { (Skill) My technique skill has increased } \\
\text { because I follow the technical training } \\
\text { provided by the company. }\end{array}$ & \\
\hline & & T3 & $\begin{array}{l}\text { (knowledge) I have joint safety training } \\
\text { within the company, it gives me the } \\
\text { necessary knowledge to work with safety. }\end{array}$ & \\
\hline & & T4 & $\begin{array}{l}\text { (Knowledge) I work in MA HOUR } \\
\text { Engineering; my knowledge has increased } \\
\text { because the company always provides } \\
\text { training workers twice a year. }\end{array}$ & \\
\hline \multirow{9}{*}{$C D$} & \multirow{9}{*}{$\begin{array}{l}\text { Career } \\
\text { Development is to } \\
\text { increase the } \\
\text { individual's ability to } \\
\text { achieve the goals } \\
\text { and achievements } \\
\text { of the company. }\end{array}$} & CD1 & $\begin{array}{l}\text { (Exposure) My ability will be increased if I } \\
\text { do not have amatter at the workplace. }\end{array}$ & \multirow{9}{*}{$\begin{array}{l}\text { (Winda et } \\
\text { al., 2017) } \\
\text { and (Arifin et } \\
\text { al., 2020). }\end{array}$} \\
\hline & & CD2 & $\begin{array}{l}\text { (Exposure) I do a job happily and } \\
\text { confidently if I don't have a matter with } \\
\text { the company. }\end{array}$ & \\
\hline & & CD3 & $\begin{array}{l}\text { (Organization Loyalty) I want to work with } \\
\text { this company because it can improve my } \\
\text { ability. }\end{array}$ & \\
\hline & & CD4 & $\begin{array}{l}\text { (Organization Loyalty) I don't want to } \\
\text { move to another company because I } \\
\text { work here, my ability will increase. }\end{array}$ & \\
\hline & & CD5 & $\begin{array}{l}\text { (Supervisor and Sponsor) The supervisors } \\
\text { always keep increasing my ability. }\end{array}$ & \\
\hline & & CD6 & $\begin{array}{l}\text { (Supervisor and Sponsor) The company } \\
\text { gives me a chance to develop my career. }\end{array}$ & \\
\hline & & & (Opportunities to grow) I have & \\
\hline & & CD7 & $\begin{array}{l}\text { opportunities to grow my knowledge when } \\
\text { I work within a company. }\end{array}$ & \\
\hline & & CD8 & $\begin{array}{l}\text { (Opportunities to grow) I have } \\
\text { opportunities to grow my technical skills, } \\
\text { and I became more proficient in the job. }\end{array}$ & \\
\hline \multirow{4}{*}{ EP } & \multirow{4}{*}{$\begin{array}{l}\text { Employee } \\
\text { Performance } \\
\text { is the requirement } \\
\text { that managers } \\
\text { ensure the } \\
\text { performance of } \\
\text { employees and the } \\
\text { results achieved by } \\
\text { employees in }\end{array}$} & EP1 & $\begin{array}{l}\text { (Declarative Knowledge) I have a } \\
\text { standard procedure to work. }\end{array}$ & \\
\hline & & EP2 & $\begin{array}{l}\text { (Declarative Knowledge) I have a target } \\
\text { for achievement. }\end{array}$ & \\
\hline & & EP3 & $\begin{array}{l}\text { (Declarative Knowledge) I have a } \\
\text { principle for problem-solving. }\end{array}$ & \\
\hline & & EP4 & $\begin{array}{l}\text { (Procedure Knowledge) I work on } \\
\text { psychomotor skills. }\end{array}$ & $\begin{array}{l}\text { (Herman, } \\
\text { 2009) }\end{array}$ \\
\hline
\end{tabular}




\begin{tabular}{|c|c|c|c|c|}
\hline & \multirow{5}{*}{$\begin{array}{l}\text { accordance with } \\
\text { the goals set by the } \\
\text { company and can } \\
\text { benefit through } \\
\text { competition. }\end{array}$} & EP5 & $\begin{array}{l}\text { (Procedure Knowledge) I have the } \\
\text { interpersonal skills to work on my own, not } \\
\text { necessarily superior checks }\end{array}$ & \\
\hline & & EP6 & $\begin{array}{l}\text { (Procedure Knowledge) I have the } \\
\text { cognitive skill to work for myself, not } \\
\text { necessarily above-superior guidance. }\end{array}$ & \\
\hline & & EP7 & (Motivation) I will go to work today. & \\
\hline & & EP8 & I will put in my best effort at work. & \\
\hline & & EP9 & (Motivation) I will persist no matter what. & \\
\hline \multirow{10}{*}{ JS } & \multirow{10}{*}{$\begin{array}{l}\text { Job Satisfaction is } \\
\text { the attitude of an } \\
\text { individual in the } \\
\text { performance of } \\
\text { their work as } \\
\text { perceived through } \\
\text { communication } \\
\text { between } \\
\text { employees and the } \\
\text { company. }\end{array}$} & JS1 & $\begin{array}{l}\text { (Work itself) I am satisfied because I do not } \\
\text { want to be absent during working hours. }\end{array}$ & \multirow{10}{*}{$\begin{array}{l}\text { (Ivancevich, } \\
\text { 1976) and } \\
\text { (Winda et } \\
\text { al., 2017) }\end{array}$} \\
\hline & & JS2 & $\begin{array}{l}\text { (Work itself) I am satisfied because I like my } \\
\text { work. }\end{array}$ & \\
\hline & & JS3 & $\begin{array}{l}\text { (Pay) I am satisfied because I get a } \\
\text { decent salary from working at this } \\
\text { company. }\end{array}$ & \\
\hline & & JS4 & $\begin{array}{l}\text { (Pay) I am satisfied because I get a lot of } \\
\text { benefits from the company. }\end{array}$ & \\
\hline & & JS5 & $\begin{array}{l}\text { (Promotion Opportunities) I am satisfied } \\
\text { because I can get a promotion if I do a } \\
\text { good job. }\end{array}$ & \\
\hline & & JS6 & $\begin{array}{l}\text { (Promotion Opportunities) I am satisfied } \\
\text { because I was able to get the opportunity } \\
\text { to be promoted in the company. }\end{array}$ & \\
\hline & & JS7 & $\begin{array}{l}\text { (Co-worker) I am satisfied because I get a } \\
\text { lot of good colleagues at work. }\end{array}$ & \\
\hline & & JS8 & $\begin{array}{l}\text { (Co-worker) I am satisfied because } \\
\text { colleagues know how to be united and } \\
\text { know how to help each other. }\end{array}$ & \\
\hline & & JS9 & $\begin{array}{l}\text { (Supervision) I am satisfied because the } \\
\text { management has the right to control the } \\
\text { work according to the role of the staff. }\end{array}$ & \\
\hline & & JS10 & $\begin{array}{l}\text { (Supervision) I am satisfied because I get } \\
\text { clear job supervision from management } \\
\text { and follow-up work properly. }\end{array}$ & \\
\hline
\end{tabular}

\section{Data Analysis}

There are three steps of analysis that we carried out in this study to analyze the data. First, we evaluate the validity items that used Correlation (Pearson Product Moment Correlation) to analyze the description of the respondent's answer to the questionnaires of the researcher through Bivariate Correlation for all the indicators of four variables. Second, we conducted the simple regression (statistic) evaluation of the two variables' impact on employee performance $(Y)$ is training $(X 1)$ and career development (X2). The statistical significance of these correlations and the number of cases based on R2 were used to measure the relationship between the independent $(X)$ and dependent variable $(Y)$. Third, we conducted multiple regression (Hierarchical Multiple Regression). These are based on $\mathrm{R}^{2}$ were used to measurement the moderator variable that has an influence relationship between the independent variable(X) and dependent variable (Y). There are block-1 to put the Independent variable(X) and block-2 for independent variable multiple by second 
moderator variable that has influence relationship on the dependent variable (Y), it is called Interaction Term (Hair, 2009).

\section{RESULTS AND DISCUSSION}

\section{Correlation}

We analyzed the correlation (Pearson Product Moment Correlation) to measure the validity items of the questionnaire in this study. This evaluation consists of two indicators: Correlation and Reliability Statistics. The correlation between an independent variable and a dependent variable is positive and statistically significant. The Reliability of a measuring instrument is defined as its ability to measure the phenomenon consistently. It is designed to measure Reliability, therefore, refers to Test Consistency. The importance of Reliability lies in the fact that it is a prerequisite for the validity of a test $(\mathrm{Ho}, 2006)$.

Table 3.

Correlation and Reliability Statistics Evaluation

\begin{tabular}{|c|c|c|c|c|c|c|}
\hline \multirow[b]{2}{*}{ Variables } & \multirow[b]{2}{*}{ Items } & \multicolumn{3}{|c|}{ Correlations } & \multicolumn{2}{|c|}{ Reliability } \\
\hline & & Pearson & Sig. (2-tailed) & $\mathbf{N}$ & $\begin{array}{c}\text { Cronbach's } \\
\text { Alpha }\end{array}$ & $\begin{array}{c}\mathrm{N} \text { of } \\
\text { Items }\end{array}$ \\
\hline \multirow{4}{*}{ Training } & $\mathrm{Tl}$ & 0.854 & \multirow{4}{*}{0.000} & \multirow{4}{*}{100} & \multirow{4}{*}{0.85} & \multirow{4}{*}{04} \\
\hline & $\mathrm{T} 2$ & 0.904 & & & & \\
\hline & T3 & 0.742 & & & & \\
\hline & $\mathrm{T} 4$ & 0.847 & & & & \\
\hline \multirow{8}{*}{ Career Development } & CD1 & 0.707 & \multirow{8}{*}{0.000} & \multirow{8}{*}{100} & \multirow{8}{*}{0.93} & \multirow{8}{*}{08} \\
\hline & CD2 & 0.789 & & & & \\
\hline & CD3 & 0.893 & & & & \\
\hline & CD4 & 0.869 & & & & \\
\hline & CD5 & 0.596 & & & & \\
\hline & CD6 & 0.913 & & & & \\
\hline & CD7 & 0.900 & & & & \\
\hline & CD8 & 0.861 & & & & \\
\hline \multirow{9}{*}{ Employee Performance } & $\mathrm{EPl}$ & 0.690 & \multirow{9}{*}{0.000} & \multirow{9}{*}{100} & \multirow{9}{*}{0.85} & \multirow{9}{*}{09} \\
\hline & EP2 & 0.663 & & & & \\
\hline & EP3 & 0.731 & & & & \\
\hline & EP4 & 0.709 & & & & \\
\hline & EP5 & 0.593 & & & & \\
\hline & EP6 & 0.599 & & & & \\
\hline & EP7 & 0.757 & & & & \\
\hline & EP8 & 0.651 & & & & \\
\hline & EP9 & 0.642 & & & & \\
\hline \multirow{10}{*}{ Job Satisfaction } & JS1 & 0.689 & \multirow{10}{*}{0.000} & \multirow{10}{*}{100} & \multirow{10}{*}{0.92} & \multirow{10}{*}{10} \\
\hline & JS2 & 0.804 & & & & \\
\hline & JS3 & 0.360 & & & & \\
\hline & JS4 & 0.861 & & & & \\
\hline & JS5 & 0.872 & & & & \\
\hline & JS6 & 0.866 & & & & \\
\hline & JS7 & 0.776 & & & & \\
\hline & JS8 & 0.806 & & & & \\
\hline & JS9 & 0.796 & & & & \\
\hline & JS10 & 0.790 & & & & \\
\hline
\end{tabular}




\section{Keomorakath PICH \\ Fendy Suhariadi}

The data collected from this research questionnaire passed the validity items because each variable was positive and statistically significant. The reliability statistics of training was 0.85 , career development was 0.93 , employee performance was 0.85 , and job satisfaction was 0.92. The results of the correlation and Reliability in this study are shown in Table 3.

\section{Simple and Multiple Regression}

We examine the simple regression to measure the structural model made for the study. The value generated from the data analysis software SPSS 26 program could be used to determine the level of the constructed model. Evaluating the strength of a predictive equation is measured by the calculated strength of the equation called R-squared, sometimes called the coefficient of determination. $R^{2}$ is simply the square of the multiple correlation coefficient listed under $\mathrm{R}$ in the model summary table. It represents the proportion of variance accounted for in the dependent variable $(Y)$ by the predictor variable $(X)$ (Ho, 2006). The result of this study's Simple Regression and Multiple Regression model evaluation is shown in Table 4.

\section{Table 4.}

Simple and Multiple Regression

\begin{tabular}{|c|c|c|c|c|c|c|c|c|c|}
\hline \multicolumn{10}{|c|}{ Model Summary } \\
\hline \multirow[b]{2}{*}{ Model } & \multirow[b]{2}{*}{$\mathbf{R}$} & \multirow[b]{2}{*}{$\mathbf{R}^{2}$} & \multirow[b]{2}{*}{ Adjust $\mathbf{R}^{2}$} & \multirow[b]{2}{*}{ Std. Error } & \multicolumn{5}{|c|}{ Change Statistics } \\
\hline & & & & & $\mathbf{R}^{2}$ & $\mathbf{F}$ & $D f_{1}$ & $\mathrm{Df}_{2}$ & Sig. $F$ \\
\hline 1 & $.334^{a}$ & .112 & .103 & .45021 & .112 & 12.309 & 1 & 98 & .001 \\
\hline 2 & $.601^{b}$ & .361 & .348 & .38365 & .250 & 37.953 & 1 & 97 & .000 \\
\hline \multicolumn{10}{|c|}{ a. Predictors: (Constant), T } \\
\hline \multicolumn{10}{|c|}{ b. Predictors: (Constant), T, Interaction Term T (JS x T) } \\
\hline 1 & $.539 a$ & .291 & .284 & .40222 & .291 & 40.196 & 1 & 98 & .000 \\
\hline 2 & $.622^{b}$ & .387 & .375 & .37585 & .096 & 15.238 & 1 & 97 & .000 \\
\hline \multicolumn{10}{|c|}{ a. Predictors: (Constant), CD } \\
\hline b. & Predictors & Cons & tant), CD, Ir & n Term CL & $\times$ CD) & & & & \\
\hline
\end{tabular}

The first evaluation of model Summary of Model- 1 shown the multiple correlation coefficient was 0.334 . The $R^{2}$ was 0.112 , and Sig. F was 0.001 . Thus, for this sample of a. Predictors: (Constant), $T$, the independent variable of $(T$ ) is training has explained $11.2 \%$ of the variance in the dependent variable of $(Y)$ is employee performance. We look further at the multiple correlation coefficient Model-2 had $R$ was $0.601^{b}, R^{2}$ was 0.361 , and Sig. $F$ was 0.000 . Thus, for this sample of b. predictor: (Constant), $T$, Interaction Term $T$ (JS $\times$ T) compared with the previous model to estimate the magnitude of the explained variance by adding the Interaction Term to the Model-2. The independent variable of (T) is training, and job satisfaction as a moderator variable ( $Z$ ) has explained $36.1 \%$ of the variance in the dependent variable of $(Y)$ is employee performance. The second evaluation of the model summary of Model-1 shown the multiple correlation coefficient was 0.539 . The $R^{2}$ was 0.291 , 
and Sig. F was 0.000. Thus, for this sample, the predictor variable of (CD) is career development has explained $29.1 \%$ of the variance in the dependent variable of $(Y)$ is employee performance. We look further at the multiple correlation coefficient Model-2 had $R$ was $0.622^{b}, R^{2}$ was 0.387 , and Sig. $F$ was 0.000 . Thus, for this sample of b. predictor: (Constant), CD, Interaction Term CD (JS x CD) compared with the previous model to estimate the magnitude of the explained variance by adding the Interaction Term to the Model-2. The independent variable of (CD) is career development, and job satisfaction as a moderator variable (Z) has explained that $38.7 \%$ of the variance in the dependent variable of $(\mathrm{Y})$ is employee performance.

\section{Hypothesis Testing}

Based on the data using structural of SPSS (Statistical Package for Social Sciences) through Simple Regression and Multiple Regression (Hierarchical Multiple Regression), the hypothesis tested for each variable as shown through $\mathrm{R}^{2}$ as mentioned:

$\mathrm{H} 1$. The correlation of Training on Employee Performance has a positive relationship at 0.112 or $11.2 \%$ and signification.

H2. The correlation of Training on Employee Performance with Job Satisfaction as a moderating variable has a positive relationship at 0.361 or $36.1 \%$ and signification.

H3. The correlation of Training on Employee Performance has a positive relationship at 0.291 or $29.1 \%$ and signification.

H4. The correlation of Training on Employee Performance with Job Satisfaction as a moderating variable has a positive relationship at 0.387 or $38.7 \%$ and signification.

The hypothesis tested through $\mathrm{R}^{2}$ is explained as follows, the independent variable affects the dependent variable, and the moderator variable has a greater influence on the relationship between the independent variable and the dependent variable. Thus, it can be concluded that $\left(H_{1}\right)$ the relationship between training and employee performance is 0.112 or $11.2 \%$, and $\left(\mathrm{H}_{2}\right)$ the relationship between training and employee performance with job satisfaction as a moderating variable has a positive relationship increasing from 0.112 to 0.361 or $11.2 \%$ to $36,1 \%$ and significant. It means that training indirectly affects employee performance through job satisfaction as a moderator variable, which is 0.249 or $24.9 \%$ greater than the direct effect of training on employee performance. So, we conclude to accept $\left(\mathrm{H}_{2}\right)$. While $\left(\mathrm{H}_{3}\right)$ the correlation of career development to employee performance is 0.291 or $29.1 \%$, and $\left(\mathrm{H}_{4}\right)$ the correlation of career development to employee performance with job satisfaction as the moderating variable has a positive relationship increasing from 0.291 to 0.387 or $29.1 \%$ to $38.7 \%$ and significant. It means that career development indirectly affects employee performance through job satisfaction as a moderator variable greater than 0.96 or $9.6 \%$ than 


\section{Keomorakath PICH \\ Fendy Suhariadi}

the direct effect of career development on employee performance. So, we conclude to accept (H4).

\section{Discussion}

For this discussion, we will analyze all two independent variables are training $\left(X_{1}\right)$ and career development $\left(\mathrm{X}_{2}\right)$ on the dependent variable is employee Performance $(Y)$, with a moderator variable is job satisfaction (Z). Instead, we run for the impact of training and career development on employee performance with job satisfaction as a moderator variable in MA HOUR EngineeringCo., Ltd in Phnom Penh City, Cambodia.

\section{The Impact of Training on Employee Performance}

The current study shows that employee performance; follows (Herman, 2009), which affects declarative knowledge such as standard procedures, target achievement, and problemsolving principles in the workplace. The impact on procedural knowledge is employee psychomotor skills, interpersonal skills, and cognitive skills work. It impacts employee motivation to want to work, try as best as possible at work, and survive no matter what. The reason might be, as indicated in the individuals' answers to the validity items and Reliability in the questionnaire, in all four questions, there are ( $\mathrm{N}$ of items $=09)$, and all validity items of training were valid. We assume that a negative and statistically significant item validity $(r=$ 0.593, $p<0.001$ ) is the lowest among them: the company's lack of achievement of employee targets. A positive and statistically significant item validity $(r=0.757, p<0.001)$ is the highest among them: employee work motivation. The results of this study showed that the level of the technical and safety training provided by an organization to learn their employee's skills and knowledge at the examined company has an impact on the performance of the employee in MA HOUR Engineering Co., Ltd because the level of practicing was level required to teach their employee in the company to develop technical skill and increase necessary knowledge to work with safety for their employee. The reason might be, as indicated in the individuals' answers to the validity items and Reliability in the questionnaire, in all four questions, there are ( $\mathrm{N}$ of items $=04$ ), and all validity items of training were valid. The validity item there is negative and statistically significant ( $r=0.742, p<0.001$ ) was lowest among them: lack of company-provided training to an employee with necessary safety training for the employee to work with safety. The validity item there is positive and statistically significant $(r=0.904, p$ $<0.001$ ) was higher among them. The technical skill of employee has increased because they are followed the technical training provided by the company. This was consistent with (Bohlander and Snell, 2010) and (Krietner, 1995). The result in this study found a positive relationship and significant follow-up to expectation training on employee performance. According to previous research, training has a distinct role in achieving an organizational 
goal by incorporating the interests of the organization and the workforce on employee performance (Afroz, 2018).

Table 4. there are essential initial pieces of information in the model summary table $R$ was 0.334 a $R^{2}$ was 0.112 or $11.2 \%$, and Sig. $F$ was 0.001 . The multiple correlation coefficient $(R)$ measures the strength of the relationship between employee performance $(Y)$ and the one predictor variable selected for inclusion in the equation. In this study, we found the $R$ was 0.334 a, which tells us there is a positive and strong relationship. By squaring $R$ was 0.112 or $11.2 \%$, we identify the value of the coefficient of multiple determination (i.e., $R^{2}$ ). This statistic enables us to determine the amount of explained variation (variance) in employee performance $(Y)$ from the predictors of training $\left(X_{1}\right)$ on a range from $0-100$ percent is $11.2 \%$. Thus, we can say that 11.2 percent of the variation in employee performance $(Y)$ is accounted for through the linear effects of the predictor variables of training through the skill and knowledge of an employee in the company; however, since we know which of the predictors has contributed significantly to our understanding of employee performance $(Y)$ in Sig. F was 0.001 .

\section{The Impact of Career Development on Employee Performance}

The current study showed employee performance consistent with (Herman, 2009), which impacted declarative knowledge such as a standard procedure, target achievement, and principle for problem-solving at work. The impact to procedure knowledge there is employee's psychomotor skill, interpersonal skill, and cognitive skill to work. The impact to motivation for employee willing go to work, best effort at work and persist no matter what. The reason might be, as indicated in the individuals' answers to the validity items and Reliability in the questionnaire, in all four questions, there are ( $\mathrm{N}$ of items $=09)$, and all validity items of training were valid. We assumed, the validity item there is negative and statistically significant $(r=0.593, p<0.001$ )was lowest among them: the lack of employee target achievement in the company, and the validity item there is positive and statistically significant $(r=0.757, p<0.001)$ was highest among of them: the motivation of employee willing got to work. The current results showed that the level of career development to increase the individual's ability to achieve the goals and achievements of the company through exposure, organization loyalty, supervisor and sponsor, opportunities to grow at the examined company has an impact on the performance of an employee in MAHOUR Engineering Co., Ltd because the level of practicing was level required to employee develop by themselves in the company to increase ability with work happily and confidently if no matter with the company, employee work with this company can improve their ability, supervisor always keeps their staff to increase ability and company give a chance for their 


\section{Keomorakath PICH \\ Fendy Suhariadi}

employee to develop their career, the employee has opportunities to grow knowledge and skill. The reason might be, as indicated in the individuals' answers to the validity items and Reliability in the questionnaire, there are ( $\mathrm{N}$ of item $=08$ ), and all validity items of career development were valid. The validity item there is negative and statistically significant $(r=$ 0.596, $p<0.001$ ) was lower among them, it is the lack of supervisor care about their staff can be increased. The validity item there is positive and statistically significant ( $r=0.913, p<0.001$ ) was higher among of them, it is the company gives their employee a chance to develop their career. This was consistent with (Winda et al., 2017) and (Arifin et al., 2020). This study found a positive relationship and significant follow-up to the expectation of career development on employee performance. Previous research found that career development indirectly affects motivation and organization support as a relationship between career development and performance. Career development is very important for employees as the activities are performed and indicated to the organization that the employee cares about their employee and them to develop (Hameed and Waheed, 2011).

Table 4. there are essential pieces of information in the model summary table: $R$ was 0.539 , $R^{2}$ was 0.291 or $29.1 \%$, and Sig. $F$ was 0.000 . The multiple correlation coefficient $(R)$ measures the strength of the relationship between employee performance $(Y)$ and the one predictor variable selected for inclusion in the equation. In this study, we found the $R$ was 0.539 , which tells us there is a positive and strong relationship. By squaring $R$ was 0.291 or $29.1 \%$, we identify the value of the coefficient of multiple determination (i.e., $R^{2}$ ). This statistic enables us to determine the amount of explained variation (variance) in employee performance ( $Y$ )from the predictors of career development $\left(X_{2}\right)$ on a range from 0-100 percent was $29.1 \%$. Thus, we can say that 29.1 percent of the variation in employee performance ( $Y$ ) is accounted for through the linear effects of the predictor variables of career development through exposure, organization loyalty, supervisor and sponsor, opportunities to grow an employee in the company, however, since we know which of the predictors has contributed significantly to our understanding of employee performance (Y) in Sig. F was 0.000.

\section{The Impact of Training on Employee Performance with Job Satisfaction as a Moderator Variable}

The current study also found that the level of the job satisfaction of the employees was moderated, which mean that the attitude of an employee in the performance of their work as perceived through communication between employees and the company there are employee satisfied to work itself, pay, promotion opportunities, co-worker, and supervision at the examined company has moderate impact between training and employee performance in MA HOUR Engineering Co., Ltd, because the level of practicing was level required to employee attitude of an individual in the performance of their work as perceived 
through communication between employee and the company such as employee were satisfied because they like a work and they do not absent during working hours, they can get opportunity to be promoted or they can get a promotion if they do an excellent job in the company, they get lots of good colleagues and they know to be unite to help each other at workplace, they get clear job supervision form management follow up on work properly and the right control the work according to the staff's role. This might be attributed to, as it is evident in the answers of the respondents of job satisfaction as a moderated between training and employee performance there are ( $\mathrm{N}$ of items $=10$ ), and all the validity items were valid. We assumed that the validity item there is negative and statistically significant $(r=$ $0.360, p<0.001$ ) was the lowest among them: the lack of employees gets a decent salary from working at this company. The validity item there is positive and statistically significant ( $r=$ 0.872, $p<0.001$ ) was highest among them: employees satisfied because they can get a promotion if they do a good job. This was consistent with (Ivancevich, 1976) and (Winda et al., 2017), which stated that the employees' job satisfaction was moderated between training and employee performance. The result in this study found a positive relationship and significant follow-up to expectation job satisfaction as a moderating variable according to previous research that results in job satisfaction moderated the relationship between predicted and actual performance. High work satisfaction appears to be a moderator when examining unexcused absences, proficiency, quality, technical competence, and task orientation. Ivancevich (1976) argues that job satisfaction is feelings or affective responses to facets of the work situation.

Table 4. there are essential pieces of information of Model- 1 and Model-2 in the model summary table for Model-1: $R$ was $0.334 a, R^{2}$ was 0.112 or $11.2 \%$, and Sig. $F$ was 0.001 . For Model-2 in that are $R$ was $0.601 a, R^{2}$ was 0.361 or $36.1 \%$, and Sig. $F$ was 0.000 . The multiple correlation coefficient $(R)$ of job satisfaction as a moderated is a measure of the influence of the relationship between training $\left(X_{1}\right)$ and employee performance $(Y)$ and the one predictor variable selected for inclusion in the equation. This study found $R$ was $0.334^{a}$ in Model-land $R$ was $0.601^{\mathrm{b}}$ in Model-2, which shows a positive and strong relationship. By squaring $R$ was 0.112 or $11.2 \%$ in Model- 1 and squaring $R$ was 0.361 or $36.1 \%$ in Model-2, we identify the value of the coefficient of multiple determination (i.e., $R^{2}$ ) of a. predictor (Constant), $T$ to compare to b. predictor (Constant), T, Interaction Term T (JS $\times$ T). This statistic enables us to determine the amount of explained variation (variance) in employee performance (Y) from the predictors of training $\left(X_{1}\right)$ on a range from $0-100$ percent is $11.2 \%$ increased to $36.1 \%$ with job satisfaction as a moderator variable (Z). Thus, we can say that 11.2 percent of the variation in employee performance $(Y)$ is accounted for through the linear effects of the predictor variable of training direct impact on employee performance without job satisfaction as a 


\section{Keomorakath PICH \\ Fendy Suhariadi}

moderator variable. We can say that 36.1 percent of the variation in employee performance $(Y)$ is accounted for through the multiple regression impact of the predictor variable of training indirect impact on employee performance with job satisfaction as a moderator variable. Again, we can say the impact of training on employee performance with job satisfaction as a moderating variable at $36.1 \%$ is greater than the impact of training on employee performance at $11.2 \%$. However, since we know between the a. predictors (Constant), $T$, and b. predictor (Constant), $T$, Interaction Term $T$ (JS $\times$ T) has contributed significantly to our understanding of employee performance $(Y)$ in Sig. F was 0.001 to 0.000.

\section{The Impact of Career Development on Employee Performance with Job Satisfaction as a Moderator Variable}

Additionally, the current study also found that the level of the job satisfaction of the employees was moderated, which mean that the attitude of an employee in the performance of their work as perceived through communication between employees and the company there were employee satisfied to work itself, pay, promotion opportunities, coworker, and supervision at the examined company has moderate impact between career development and employee performance in MA HOUR Engineering Co., Ltd, because the level of practicing was level required to employee attitude of an individual in the performance of their work as perceived through communication between employee and the company such as employee were satisfied because they like a work and they do not absent during working hours, they can get opportunity to be promoted or they can get a promotion if they do a good job in the company, they get lots of good colleagues and they know to be united to help each other at workplace, they get clear job supervision form management follow-up on work properly and the right control the work according to the staff's role. This might be attributed to, as it is evident in the answers of the respondents of job satisfaction as a moderated between training and employee performance there are $(\mathrm{N}$ of items $=10$ ), and all the validity items were valid. We assumed that the validity item there is negative and statistically significant $(r=0.360, p<0.001)$ was the lowest among them: the lack of employees gets a decent salary from working at this company. The validity item there is positive and statistically significant ( $r=0.872, p<0.001)$ was highest among them: employees satisfied because they can get a promotion if they do a good job. This was consistent with (Ivancevich, 1976) and (Winda et al., 2017), which stated that the employees' job satisfaction was moderated between training and employee performance. This study found a positive relationship and significant follow-up to expectation job satisfaction as a moderating variable. According to previous research, the researcher found that job satisfaction significantly impacts employee performance. Paramita et al. (2020) argue that job satisfaction is the individual's general attitude to the job. The individual must interact with 
co-workers and superiors, follow organizational rules and policies, and meet performance standards.

Table 4. there are essential pieces of information of Model-1 and Model-2 in the model summary table for Model-1: $R$ was $0.539 a, R^{2}$ was 0.291 or $29.1 \%$, and Sig. $F$ was 0.000 . In Model-2 for $R$ was $0.622^{b}, R^{2}$ was 0.387 or $38.7 \%$, and Sig. $F$ was 0.000 . The multiple correlation coefficient $(R)$ of job satisfaction as a moderated is a measure of the influence of the relationship between career development $\left(X_{2}\right)$ and employee performance $(Y)$ and the one predictor variable selected for inclusion in the equation. In this study, we found the $R$ was 0.539 in Model- 1 and $R$ was $0.622^{\mathrm{b}}$ in Model-2 were told there is a positive and strong relationship. By squaring $R$ was 0.291 or $29.1 \%$ in Model- 1 and $R$ was 0.387 or $38.7 \%$ in Model-2, we identify the value of the coefficient of multiple determination (i.e., $R^{2}$ ) of a. predictor (Constant) CD to compare to b. predictor (Constant), CD, Interaction Term CD (JS X CD). This statistic enables us to determine the amount of explained variation (variance) in employee performance $(Y)$ from the predictors of career development $\left(X_{2}\right)$ on a range from 0-100 percent was $29.1 \%$ increased to $38.7 \%$ with job satisfaction as a moderator variable (Z). Thus, we can say that 29.1 percent of the variation in employee performance( $Y$ ) is accounted for through the linear effects of the predictor variable of career development's direct impact on employee performance without job satisfaction as a moderator variable. We can say that 38.7 percent of the variation in employee performance $(Y)$ is accounted for through the multiple regression impact of the predictor variable of career development indirect impact on employee performance with job satisfaction as a moderator variable. Again, we can say the impact of career development on employee performance with job satisfaction as a moderator variable at $38.7 \%$ is greater than the impact of career development on employee performance at $29.1 \%$. However, we know between the $a$. predictors (Constant)CD and $b$. predictor (Constant), CD, Interaction Term CD (JS x CD) has contributed significantly to our understanding of employee performance (Y) in Sig. $F$ was 0.000 also.

\section{CONCLUSION}

The current study achieved its objectives in analyzing the impact of the training and career development on employee performance with job satisfaction as a moderating variable in MA HOUR Engineering Co., Ltd located in Cambodia. This study focuses on the training and career development impact on employee performance, with job satisfaction as a moderator. Data survey sample using census were participants and the research subject recruit all the 100 respondents to participate in getting the research object. In this study, the researcher used individuals to answer the 31 questionnaires related to the company's training to teach employee skill and knowledge and career development to increase 


\section{Keomorakath PICH \\ Fendy Suhariadi}

individual's abilities. Employee performance requires the manager to ensure the employee and the employee achieved according to the company's goal, and job satisfaction of employee's attitude to performing their work through communication between employee and company. The finding of the results in this study indicated that the level of impact of training on employee performance influences relationships at the MA HOUR Engineering Co., Ltd. The impact of job satisfaction as a moderator variable was increased influence of the relationship between training and employee performance at the MA HOUR Engineering Co., Ltd. It means that the impact of training on employee performance at theMA HOUR Engineering Co., Ltd. There is a greater chance of job satisfaction in improving the relationship between training and employee performance at the MA HOUR Engineering Co., Ltd. The level impact of career development on employee performance influences relationships at the MA HOUR Engineering Co., Ltd. The impact of job satisfaction as a moderator variable was increased influence of the relationship between career development and employee performance at the MA HOUR Engineering Co., Ltd. It means that the impact of career development on employee performance at the MA HOUR Engineering Co., Ltd. There is a greater chance of job satisfaction in improving the relationship between career development and employee performance at the MA HOUREngineering Co., Ltd.

Furthermore, the data collected from the questionnaire is used to get the level of impact of training and career development on employee performance in the company. The process can be done by adopting a similar approach to this thesis's research or developing a comprehensive analytical model using various SPSS techniques for descriptive statistics and regression. Descriptive statistics are useful for analyzing the characteristic of a respondent, and regression is useful for analyzing the result of the respondent answers the questionnaire for the researcher. The researcher suggests that further research should focus on larger populations to ensure solid empirical evidence of training and career development impact on employee performance with job satisfaction as a moderating variable in different types of business to evaluate their impact at a better level.

\section{ACKNOWLEDGEMENT}

This research has finished from all respondents who work at MA HOUR Engineering Co., Ltd. has provided data and information assistance during the implementation researchers and has been supported by Prof. Fendy Suhariadi as a Head of the Doctoral Program in Human Resource Development, Psychology Faculty, Post Graduate School University Airlangga, Surabaya, Indonesia 60115, Email: Fendy.Suhariadi@psikology.uniar.ac.id. 


\section{REFERENCES}

Afroz, N. N. 2018. Effects of Training on Employee Performance: A Study on Banking Sector, Tangail Bangladesh= آثار التدريب على أداء الموظفين: دراسة عن القطاع المصرفي، تانغيل بنغلاديش. Global Journal of Economic and Business, 427(5977): 1-14.

Ahmad, U. 2013. Impact of training on employee retention. Case Business School.

Arifin, A. H., Raza, H., Saputra, J., and Puteh, A. 2020. The Influence Of Recruitment And Career Development Towards Employee Performance: A Mediating Role Of Competence. Journal of Talent Development and Excellence, 12 (1): 1040-1055.

Bohlander, G., and Snell, S. 2010. Principles of Human Resource. Management, 15th ed. Mason, OH: South Western-Cengage Learning.

Hafeez, U., and Akbar, W. 2015. Impact of training on employees performance (Evidence from pharmaceutical companies in Karachi, Pakistan). Business Management and Strategy, 6(1): 49-64.

Hair, J. F. 2009. Multivariate data analysis.

Hameed, A., and Waheed, A. (2011). Employee development and its affect on employee performance a conceptual framework. International journal of business and social science, 2(13).

Herman, A. 2009. Performance management. River New Jersey: Pearson Education inc. Upper Saddle.

Ho, R. 2006. Handbook of univariate and multivariate data analysis and interpretation with SPSS: CRC press.

Ivancevich, J. M. 1976. Predicting job performance by use of ability tests and studying job satisfaction as a moderating variable. Journal of Vocational Behavior, 9(1): 87-97.

Krietner, S. 1995. The good manager's guide 1st edition Synene Publishers.

McGhee Et Al 1996. Nature of Learning 1st edition McGraw-Hill Book Company., Boston, USA.

Paramita, E., Lumbanraja, P., and Absah, Y. 2020. The Influence of Organizational Culture and Organizational Commitment on Employee Performance and Job Satisfaction as a Moderating Variable at PT. Bank Mandiri (Persero), Tbk. Tbk. International Journal of Research and Review, 7(3): 273-286. 
Keomorakath PICH

Fendy Suhariadi

Suhariadi, F. 2013. Manajemen Sumber Daya Manusia: Dalam Pendekatan Teoretis-Praktis: Airlangga University Press.

Winda, O., Nayati, U. H., and Arik, P. 2017. Impact of compensation and career development on job satisfaction and employees performance. Russian Journal of Agricultural and Socio-Economic Sciences, 64(4). 